\title{
STEPHANOFILARIA BOOMKERI N. SP., AS A CAUSE OF SEVERE SKIN DISEASE IN PIGS IN ZAIRE
}

\author{
BAIN O.*, VAN DER LUGT J.** \& KAZADI L.M. *** \\ with the technical assistance of TCHEPRAKOFF R."
}

\begin{abstract}
Summary :
A new Stephanofilaria, S. boomkeri n. sp., is described as the cause of skin lesions in pigs in Zaire. It is the first species described in suids. The reservoirs might be wild African suids. The six valid species of the genus Stephanofilaria form two main groups. In one group, female worms lay sheathed microfilariae members of this group are exclusively African and are represented by the parasite of rhinoceros, S. dinnicki, and hippopotamus, S. thelazioides. Their morphology is primitive. In the other group, female worms lay particular " eggs" which contain microfilariae. S. boomkeri belongs to this group, and is regarded by its cephalic structures as the most primitive representative in this group. The other species S. dedoesi and S. zaheeri. parasitize cattle in the Asiatic region. In the holarctic region, another parasite of cattle, S. stilesi, seems to be a highly specialized member of this second group. In this species as in S. boomkeri, the envelope of the "egg " is very thick and complex, probably from peculiar adaptations in order to withstand the dessication of the microfilaria.

The genus Stephanofilaria seems to have an Aethiopian origin, as in this region the species are more primitive and more varied as are also their hosts.
\end{abstract}

KEY WORDS : skin disease, pig, Africa, stephanofilariasis, systematics.
Résumé : STEPHANOFILARIA BOOMKERI N. SP., CAUSE DE GRAVES LÉSIONS CUTANÉES DU PORC AU ZAIRE.

Un élevage de porcs au Zaïre présente de graves lésions cutanées caractéristiques de stéphanofilariose. Elles sont en effet dues à un Stephanofilaria, qui est une nouvelle espèce, S. boomkeri n. sp., la première décrite chez les Suidés. Les réservoirs pourraient être les Suidés sauvages africains. Les six espèces du genre Stephanofilaria forment deux principaux groupes. Dans l'un, les femelles pondent des microfilaires à gaine ce groupe, exclusivement africain, est représenté par le parasite du Rhinocéros, S. dinnicki, et le parasite de l'Hippopotame, S. thelazioides; leur morphologie générale est primitive. Dans l'autre groupe, les femelles pondent des ceuts particuliers qui contiennent une microfilaire; S. boomkeri n. sp. appartient à ce groupe et en est le représentant le plus primitif par sa structure céphalique; les autres espèces sont parasites du bétail en région asiatique, S. dedoesi et $\mathrm{S}$. zaheeri. En région holarctique, un autre parasite du bétail, S. stilesi, semble être une forme hyperspécialisée de ce second groupe. L'enveloppe de l'œut, très épaisse et complexe chez cette espèce comme chez S. boomkeri, résulterait d'adaptations particulières empêchant la dessication de l'embryon.

Le genre Stephanofilaria semble avoir une origine éthiopienne car les espèces y sont plus primitives et plus variées, comme le sont aussi leurs hôtes

MOTS CLÉS : lésions cutanées, porc, Afrique, stéphanofilariose, systématique
Formalin fixed skin samples from pigs were submitted to one of us (JJvdL) for evaluation. The specimens originated from a pig farm in Zaire, where an outbreak of ulcerative dermatitis in pigs was encountered. Lesions occurred in adult sows, predominantly on the teats and less commonly on the ears and legs. Histopathological examination of the skin tissues revealed epidermal hyperplasia, dermatitis and nematode worms in the affected dermis. Following dissection of the fixed skin samples, fragmented portions of female and male worms were recovered. A morphological study showed

\footnotetext{
* Laboratoire de Biologie Parasitaire, Protistologie, Helminthologie, Muséum National d'Histoire Naturelle, 61, rue Buffon, 75231 Paris Cedex 05, France.

** Onderstepoort Veterinary Institute, Section of Pathology, PO Box 12502, Onderstepoort 0110, South Africa.

***Pathology Service, Veterinary Laboratory, PO Box 8842, Kinshasa, Zaire.
}

that they represent a new species of Stephanofilaria. Its interest is also phylogenetic, because it is the first representative of the genus in suids.

\section{MATERIAL}

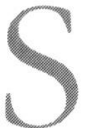
everal histological sections of infected skin and several worms dissected out from the skin were available. Female worms: seven anterior regions, of which one is the holotype, and four posterior regions. Male worms: two anterior regions, and two posterior regions, of which one is the allotype. All specimens are registered under the number $158 \mathrm{SE}$. Type specimens and several paratype specimens are housed in the MNHN collections of Paris, the other paratypes are in the Onderstepoort Veterinary Institute collections. 


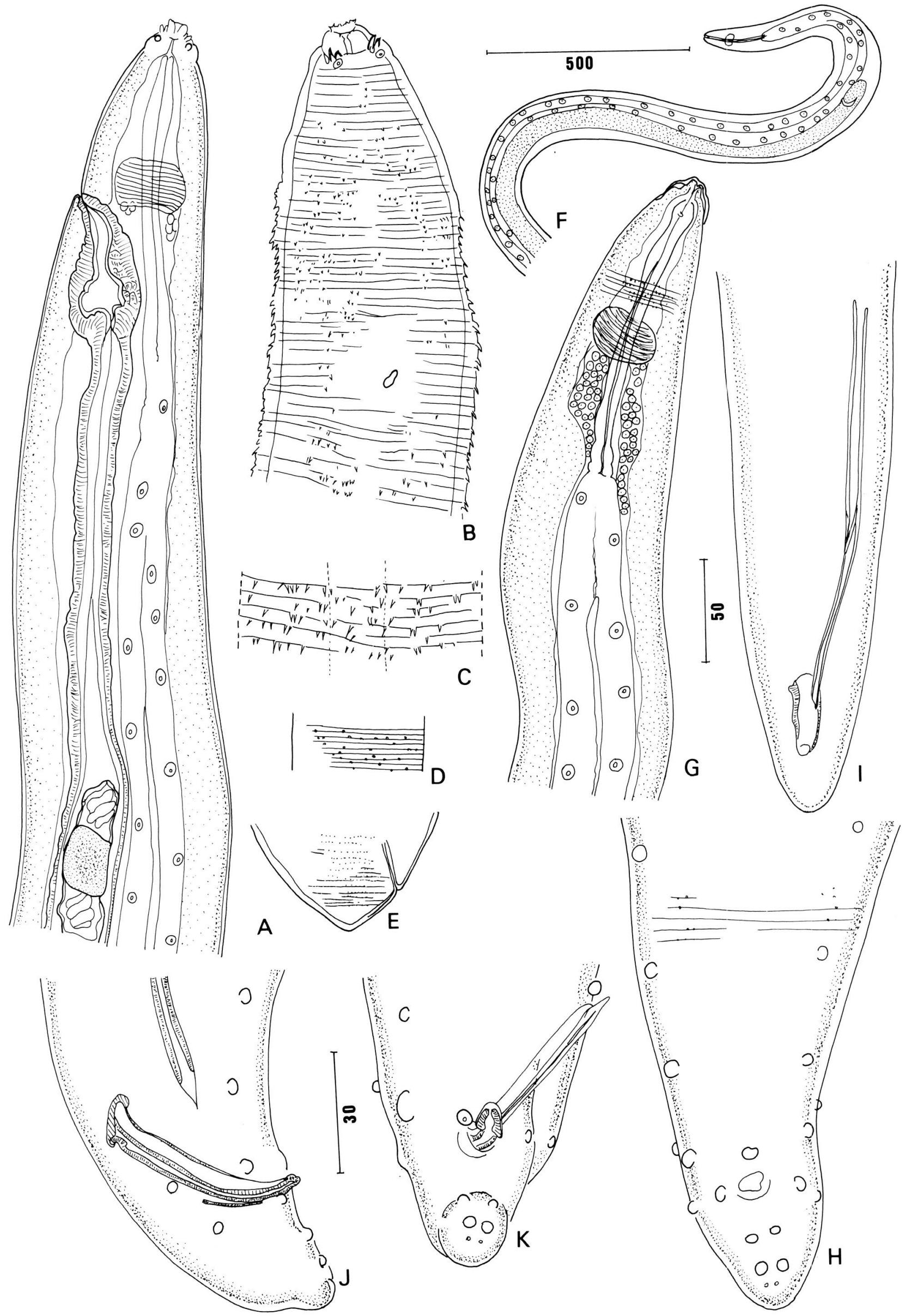


Fig. 1. - Stephanofilaria boomkeri n. sp.

A to E, female; A: paratype, anterior region, lateral view (frills not drawn); B: holotype, ventral view (frills drawn); C: idem, detail of cuticular frills, at $200 \mu \mathrm{m}$ from apex, lateral view; D: paratype, cuticular frills $1 \mathrm{~mm}$ from the caudal extremity, lateral view (a small surface of the worm is presented); E: female tail, lateral view.

F to K, male; F: anterior fragment of a paratype; G: idem, anterior region with head covered by a cap of host tissue reaction, median view (frills drawn anterior to nerve ring); $\mathrm{H}$ to J, allotype; $\mathrm{H}$ : caudal region, ventral view (end of frills drawn); I: spicules, ventral view; $\mathrm{J}$ : tail, lateral view; K: paratype, caudal region and extremities of the spicules, ventral view (scales: F, $500 \mu \mathrm{m} ; \mathrm{A}, \mathrm{E}, \mathrm{G}, \mathrm{J}, 50 \mu \mathrm{m} ; \mathrm{B}, \mathrm{C}$, $\mathrm{D}, \mathrm{H}, \mathrm{J}, \mathrm{K}, 30 \mu \mathrm{m})$.
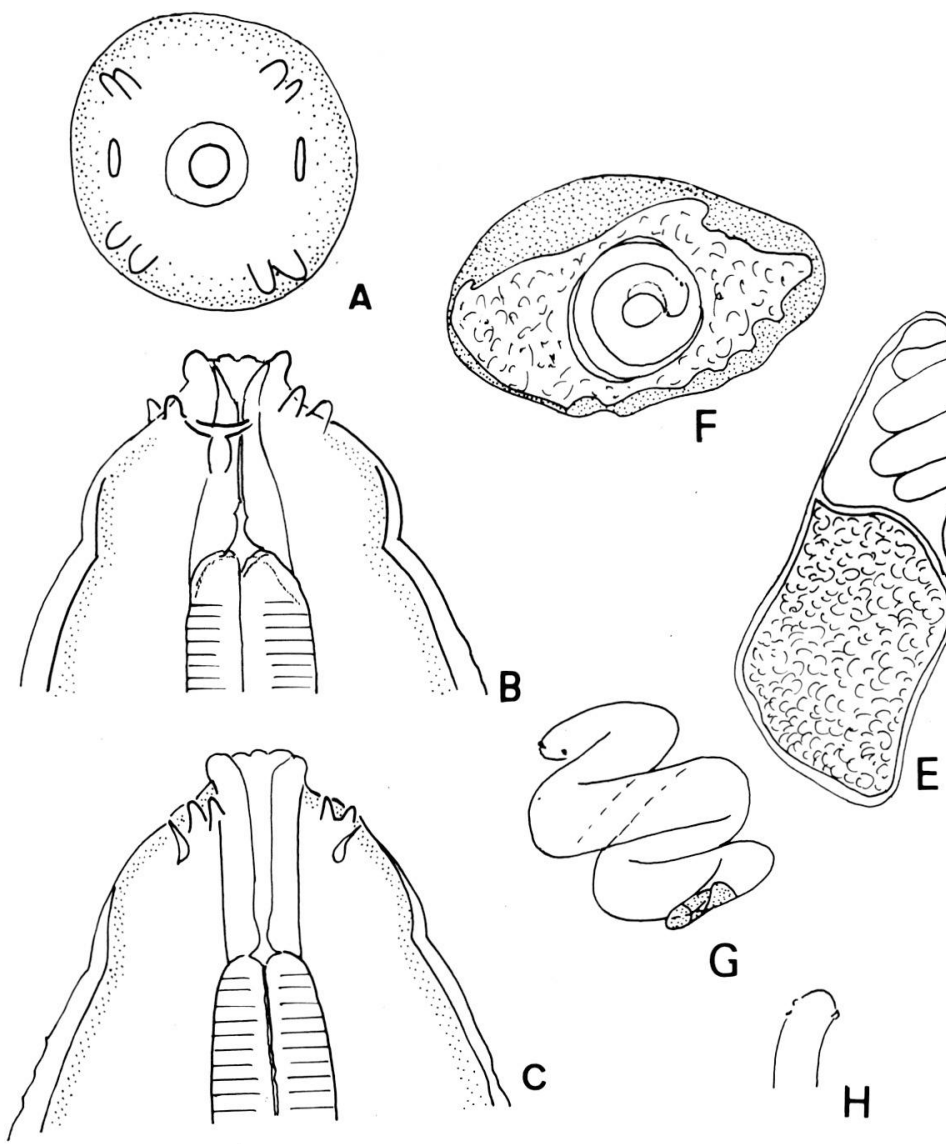

$E$

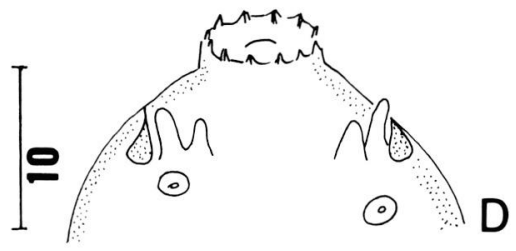

Fig. 2. - Stephanofilaria boomkeri $n$. sp.

A to D, head; A: apical view of a female paratype to show the position of the 8 external labial papillae and the peribuccal ring; B and C: other female paratype, lateral and median views (internal spines not visible in these paratypes); D: holotype, showing the crown of the 12 internal labial spines in semi-apical view.

E: microfilaria in an " egg ", its soft envelope compressed and distorted in the ovijector; F: microfilaria in egg almond-shaped after extraction from the ovijector; G: same microfilaria, from a profile view of the egg (last caudal nuclei represented); $\mathrm{H}$ : head of the microfilaria, ventral view (scale $20 \mu \mathrm{m}$ ). 


\section{DESCRIPTION}

Female (Figs. 1 et 2)

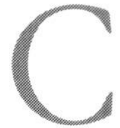

uticle of the body with frills; the spines are soft, directed posteriorly and irregular; they are sparse and small in the cervical region; they reach a maximum length $(2 \mu \mathrm{m})$ and density between 100 and $500 \mu \mathrm{m}$ approaching from the head (Fig. 1C); posteriorly and far to the tail, they are again very tiny (Fig. 1D). Deirids not observed.

Head with projecting cuticular ring bearing very small spines, 12 in number in the type specimen (Fig. 2D); in other specimens, the spines were blunt or hidden under a cap of reactive tissue of the host (Fig. 2A). At the basis of the peribuccal ring, there are four pairs (or bifid) of conspicuous submedian spines, which correspond to the four external-labial papillae, each divided, and two amphids. There are four cephalic papillae placed at the base of the spines, seen only on the type specimen. Buccal cavity flattened laterally.

Vulva and nerve ring both at mid-length of the oesophagus (Fig. 1A). Intestine with thick wall and thin lumen. Tail conical and very short.

Ovaries coiled in the posterior region, like other Stephanofilaria species; uteri parallel and fused at $750 \mu \mathrm{m}$ from the vagina. Several mature female show that no free microfilariae are present in the ovijector; each is enclosed in a large egg-shaped envelope (Fig. 2E, F, $\mathrm{G})$. The microfilaria is tightly coiled in helix; its head bears a hook, and two small spines on the opposite side; its caudal extremity is rounded and nucleated. The envelope of the " egg " presents a complex structure and is variable in shape, showing that it is not rigid. When compressed in the ovijector (Fig. 1A), the microfilaria is in an anterior cavity lined by a double thin membrane; the posterior part of the egg is dilated by a voluminous body placed between the inner and outer egg membranes. After extraction from the female worm, the internal body becomes uniformely distributed; the egg becomes almond-shaped, and its cavity central. The external egg membrane is granular and not rigid. The substance between the inner and outer surfaces of the egg-shell has a consistency difficult to define; after fixation it seems gelatinous but it could be fluid on fresh material. The egg-shell thickens during the intra-uterine embryogenesis.

Measurements: the longest fragment (which is an anterior part) is $4,35 \mu \mathrm{m}$ long and $200 \mu \mathrm{m}$ wide. Holotype and a paratype: buccal cavity $17-20 \mu \mathrm{m}$ high, externallabial papillae 8-6 $\mu \mathrm{m}$ from apex, nerve ring at 70$90 \mu \mathrm{m}$, and vulva at 85-100 $\mu \mathrm{m}$ from apex; oesophagus 170-160 $\mu \mathrm{m}$ long. Tail of two paratypes: 9-16 $\mu \mathrm{m}$. Egg extracted from the ovijector $52 / 30 \mu \mathrm{m}$ in larger dia- meters, with a central spherical cavity $15 / 18 \mu \mathrm{m}$; microfilariae $80 \mu \mathrm{m}$ long (approximately) and $6 \mu \mathrm{m}$ wide.

\section{MALE}

Frills similar to that of the female worm but more tenuous. Peribuccal ring with spines too small to be counted. Four pairs of external labial spines. Cephalic papillae not seen.

Caudal alae absent. Papillae not pedunculated: one precloacal papilla, two subventral postcloacal pairs, and the phasmids; seven lateral-ventral pairs, of which the most posterior is paracloacal; two lateral pairs, one paracloacal and one precloacal in position. The papillae are small but conspicuous on the tail itself; the most anterior lateral-ventral papillae are hardly perceptible and their number is not certain.

Left spicule with shaft and lamina equal in length, and pointed distal extremity; right spicule short and stout, with a small subterminal dorsal heel and a rounded distal extremity. Gubernaculum simple.

Measurements: the longest fragment (which is an anterior part) is $1,72 \mathrm{~mm}$ long and $150 \mu \mathrm{m}$ wide. Anterior region of two paratypes: buccal cavity 20-18 $\mu \mathrm{m}$ long; nerve ring 90-70 $\mu \mathrm{m}$ from apex; oesophagus 165$165 \mu \mathrm{m}$ long; anterior loop of the testis $500 \mu \mathrm{m}$ from the apex. Posterior regions of the allotype and a paratype: tail $32-30 \mu \mathrm{m}$ long; left spicule $220-230 \mu \mathrm{m}$ long with shaft $110-120 \mathrm{~mm}$ long; right spicule $55-50 \mu \mathrm{m}$ long; gubernaculum 15-10 $\mu \mathrm{m}$ long.

\section{DISCUSSION}

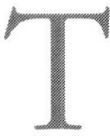
he genus Stephanofilaria Ihle \& Ihle-Landenberg, 1933 has been recently analysed by Boomker et al. (1995). Nine taxa have been proposed. Two are species inquirandae: S. andamani Sinha \& Das, 1958, a parasite of the water buffalo, Bubalus bubali, in the Andaman islands, and S. srivastavi Bhattacharjee, 1967, a parasite of the asiatic elephant, Elephas maximus, in India. Three taxa are probable synonyms of the type species $S$. dedoes $i$ Ihle \& Ihle-Landenberg, 1933, described from cattle in Indonesia: S. assamensis Pande, 1936, S. kaeli Buckley, 1937, and S. okinawaensis Ueno \& Chibana, 1977, all from cattle, respectively in India, Malaysia and south of Japan. The four other valid species are $S$. zabeeri Singh, 1958, a parasite of Bubalus bubali in Pakistan, S. stilesi Chitwood, 1934, described from Bos taurus in North-America, and found later in Russia, $S$. dinniki Round, 1964, a parasite of the black rhinoceros, Diceros bicornis, in Kenya, and S. thelazioides Boomker, Bain, Chabaud et Kriek, 1995, a parasite of Hippopotamus africanus, in South Africa. Boomker et al. (1995) proposed a phyletic classification of these species based 
on the number and position of the spines on the head; these spines derive from the six internal labial papillae and the four external labial papillae of the Thelazioid ancestors. The discussion follows this classification. Our specimens resemble $S$. dinniki and $S$. thelazioides in the primitive cephalic structure: small number of internal labial spines (six bifid in thelazioides, 12 equidistant in dinnicki and our material), four pairs of external labial spines. However these two species differ from our specimens by numerous characters: vulva near the mouth and vulvar tube very elongated, nerve ring near the oesphageal-intestinal junction, no frills on the cuticle of the body, tail of the female longer than wide and with rounded extremity, spicules and gubernaculum three-four times longer, caudal alae present with papillae pedunculated; in addition, the male of $S$. thelazioides has an area rugosa. In the above two species, the ultimate stage of embryogenesis present in the ovijector is a sheathed microfilaria.

The three other species lay " eggs " containing microfilariae as do our specimens.

However, $S$. dedoesi and its close relative, the species $S$. zaheeri, are distinct from our specimens by the more evolved cephalic structure: 15 spines or more forming the internal labial crown, external labial spines multiplied (16 to 32) forming a second posterior crown. The other distinctive characters are the denser frills and the egg with thin and simple membrane, from which the microfilaria escapes easily (Ramachandran et al., 1966; Singh, 1958, respectively for $S$. dedoesi and $S$. zaheeri). Moreover, the microfilaria of $S$. dedoesi is longer $(140 \mu \mathrm{m})$, the mature egg of $S$. zaheeri is smaller $(36-39 / 23-29 \mu \mathrm{m})$.

$S$. stilesi is distinct by the very specialized cephalic morphology (five submedian lateral-ventral spines, in Hibler, 1966 and Anderson, 1968), the frills absent, the non coiled and shorter microfilaria (40-60 $\mu \mathrm{m}$ instead of $80 \mu \mathrm{m})$, the larger egg $(67 / 50 \mu \mathrm{m}$ instead of $52 / 30 \mu \mathrm{m})$. The egg envelope, which resembles that of our specimens, presents in addition internal biconcave bodies, grouped close to the microfilaria (Hibler, 1966). The specimens from the pig in Zaire represents a new species, Stephanofiaria boomkeri $n$. sp., dedicated to our colleague, Professor J. Boomker.

\section{CONCLUSION}

The cutaneous disease of pigs, which had broken out in a piggery in Zaire, is caused by a particular parasite, Stephanofilaria boomkeri n. sp. Wild African suids, such as warthogs, might be the reservoirs.

The six species in the genus Stephanofilaria do not represent an homogeneous line. S. boomkeri has primitive cephalic characters, like the two other species present in the Aethiopian region, S. dinnicki from rhinoceros and $S$. thelazioides from hippopotamus, but these two last form a distinct group, because they lay sheathed microfilariae. The new species, which lay " eggs ", is close to the branch formed by the species parasite of cattle in Asiatic region, S. dedoesi-S. zaheeri, of which it is a primitive representative. S. stilesi, which also lays eggs, but which has a very peculiar cephalic structure and a cuticle without frills, may be considered as a highly specialized representative of this branch, or a distinct branch.

A priori the species with sheathed microfilariae are more evolved than those which lay eggs. However, in the case of Stephanofilaria, the eggs are peculiar and contain a microfilaria. Moreover, it is noted that the adult morphology of the species with microfilariae is more primitive than that of the " oviparous " species: female tail less atrophied, caudal alae of the male present. Thus it is conceivable that, in this case, the " oviparous "species would derive from those with microfilariae, either directly, or through a common ancestor. The more complex anatomy of the egg envelope is observed in two distant species, $S$. boomkeri and $S$. sitlesi, showing its adaptative value. As suggested by Hibler (1966) for S. stilesi, it could enable the microfilaria to withstand drying before being ingested by the muscine or stomoxine vectors.

The representatives of the two main groups, with sheathed microfilariae and with " eggs ", are present in the Aethiopian region (Zaire, Kenya, South Africa) and they are morphologically primitive. It is also in this region that the hosts are the most varied: artiodactyls such as suids and the hippopotamus, perissodactyls such as the rhinoceros. These observations strengthen the conclusions of Boomker et al. (1995) who propose an African origin for the genus Stephanofilaria.

\section{REFERENCES}

ANDERSON R.C. The comparative morphology of cephalic structures in the superfamily Filarioidea (Nematoda). Cana dian Journal of Zoology, 1968, 46, 181-199.

Boomker J, Bain O., Chabaud A. \& Kriek N.P.J. Stephanofi laria thelazioides n. sp. (Nematoda: Filariidae) from a hippopotamus and its affinities with the species parasitic in the African black rhinoceros. Systematic Parasitology, 1995, 32, 205-210.

Hibler C.P. Development of Stephanofilaria stiles $i$ in the horn fly. Journal of Parasitology, 1966, 52, 890-898.

Ramachandran C.P., Loke Y.M. \& Nagendram C. Studies on Stephanofilaria kaeli in cattle. Medical Journal of Malaya, 1966, 20, 344-347.

SingH S.N. On a new species of Stephanofilaria causing dermatitis of buffaloes' ears in Hyderabad (Andhra Pradesh) India. Journal of Helminthology, 1958, 32, 239-250.

Reçu le 20 mai 1996 Accepté le 26 septembre 1996 